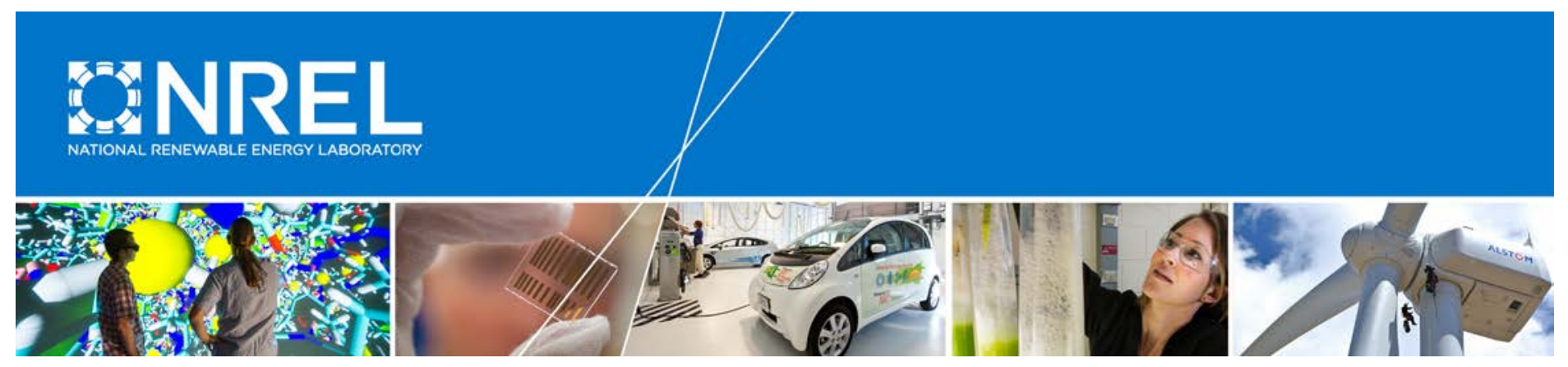

\title{
High-Penetration Photovoltaic Planning Methodologies
}

David Wenzhong Gao Alternative Power Innovations, LLC

Eduard Muljadi, Tian Tian, and Mackay Miller National Renewable Energy Laboratory

NREL is a national laboratory of the U.S. Department of Energy Office of Energy Efficiency \& Renewable Energy Operated by the Alliance for Sustainable Energy, LLC

This report is available at no cost from the National Renewable Energy Laboratory (NREL) at www.nrel.gov/publications.

Technical Report

NREL/TP-5D00-64227

February 2017

Contract No. DE-AC36-08G028308 


\section{High-Penetration Photovoltaic Planning Methodologies}

D. Wenzhong Gao

University of Denver

Eduard Muljadi, Tian Tian, and Mackay Miller National Renewable Energy Laboratory

Prepared under Task Nos. IGIN.1840, IGIN.1850

NREL is a national laboratory of the U.S. Department of Energy Office of Energy Efficiency \& Renewable Energy Operated by the Alliance for Sustainable Energy, LLC

This report is available at no cost from the National Renewable Energy Laboratory (NREL) at www.nrel.gov/publications.

National Renewable Energy Laboratory 15013 Denver West Parkway Golden, CO 80401

303-275-3000 • www.nrel.gov

\section{Technical Report}

NREL/TP-5D00-64227

February 2017

Contract No. DE-AC36-08GO28308 


\section{NOTICE}

This report was prepared as an account of work sponsored by an agency of the United States government. Neither the United States government nor any agency thereof, nor any of their employees, makes any warranty, express or implied, or assumes any legal liability or responsibility for the accuracy, completeness, or usefulness of any information, apparatus, product, or process disclosed, or represents that its use would not infringe privately owned rights. Reference herein to any specific commercial product, process, or service by trade name, trademark, manufacturer, or otherwise does not necessarily constitute or imply its endorsement, recommendation, or favoring by the United States government or any agency thereof. The views and opinions of authors expressed herein do not necessarily state or reflect those of the United States government or any agency thereof.

This report is available at no cost from the National Renewable Energy Laboratory (NREL) at www.nrel.gov/publications.

Available electronically at SciTech Connect http:/www.osti.gov/scitech

Available for a processing fee to U.S. Department of Energy and its contractors, in paper, from:

U.S. Department of Energy

Office of Scientific and Technical Information

P.O. Box 62

Oak Ridge, TN 37831-0062

OSTI http://www.osti.gov

Phone: 865.576.8401

Fax: 865.576.5728

Email: reports@osti.gov

Available for sale to the public, in paper, from:

U.S. Department of Commerce

National Technical Information Service

5301 Shawnee Road

Alexandra, VA 22312

NTIS http://www.ntis.gov

Phone: 800.553 .6847 or 703.605 .6000

Fax: 703.605.6900

Email: orders@ntis.gov 


\section{Acknowledgments}

This report was funded under the U.S.-China Renewable Energy Partnership through the U.S. Department of Energy's Office of Energy Efficiency and Renewable Energy's International Team. The authors would like to thank the U.S.-China Renewable Energy Partnership team for the opportunity to collaborate on the scoping and development of this study.

For their extensive reviews and comments, the authors would like to thank Antonio Ginart from Sonnenbatterie; Michael Ernst from Bernafon AG; Arlene Fetizanan from the U.S. Department of Energy; and Yingchen Zhang, John Barnett, James Cale, and Benjamin Kroposki from the National Renewable Energy Laboratory (NREL). The authors also thank Katie Wensuc of NREL for editorial review and support. Any errors or omissions are solely the responsibility of the authors. 


\section{List of Acronyms}

DER

FERC

HPPV

IEC

IEEE

MPPT

PV

SCADA distributed energy resources

Federal Energy Regulatory Commission

high-penetration photovoltaic

International Electrotechnical Commission

Institute of Electrical and Electronics Engineers

maximum power point tracking

photovoltaic

supervisory control and data acquisition 


\section{Executive Summary}

The main objective of this report is to provide an overview of select U.S. utility methodologies for performing high-penetration photovoltaic (HPPV) system planning and impact studies. This report covers the Federal Energy Regulatory Commission's orders related to photovoltaic (PV) power system interconnection, particularly the interconnection processes for the Large Generation Interconnection Procedures and Small Generation Interconnection Procedures. In addition, it includes U.S. state interconnection standards and procedures. The procedures used by these regulatory bodies consider the impacts of HPPV power plants on the networks. Technical interconnection requirements for HPPV voltage regulation include aspects of power monitoring, grounding, synchronization, connection to the overall distribution system, back-feeds, disconnecting means, abnormal operating conditions, and power quality. This report provides a summary of mitigation strategies to minimize the impact of HPPV. Recommendations and revisions to the standards may take place as the penetration level of renewables on the grid increases and new technologies develop in future years. 


\section{Table of Contents}

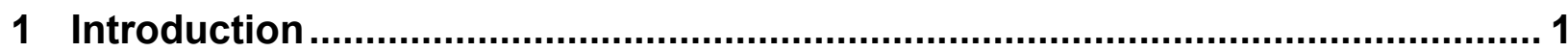

2 Federal Energy Regulatory Commission Orders …............................................ 2

3 System Interconnection Process …............................................................... 3

3.1 Large Generator Interconnection Procedure …………………………………………….... 3

3.2 Small Generator Interconnection Procedure ………………………………………………... 3

4 State Interconnection Standards and Procedures.......................................... 5

5 Impacts of HPPV Power Plants..................................................................... 7

6 Technical Interconnection Requirements of HPPV ............................................ 9

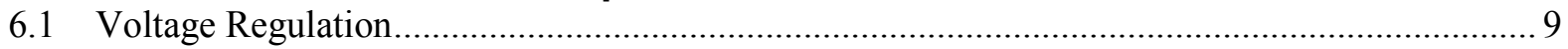

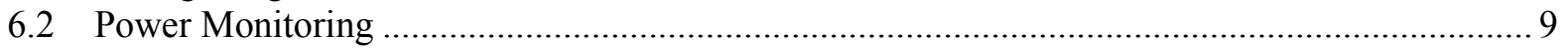

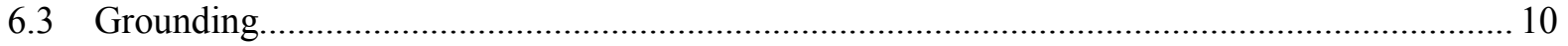

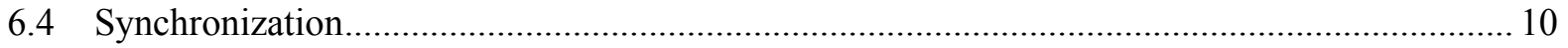

6.5 Connection to the Distribution System ………………………………………………….... 10

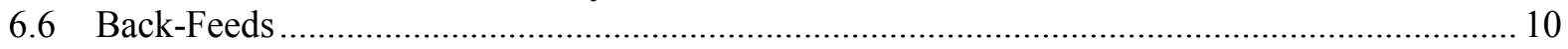

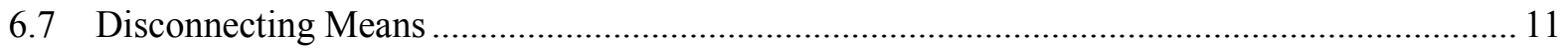

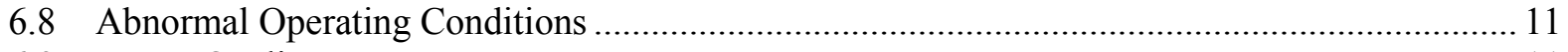

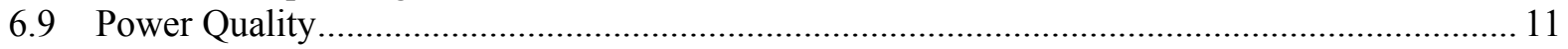

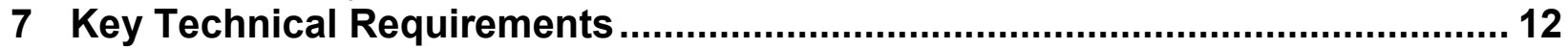

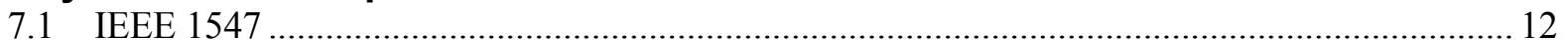

7.2 FERC Order 661A - Appendix G of the Large Generator Interconnection Agreement.............. 14

8 PV Power Plant Design, Engineering Studies, and System Interconnections . 15

9 Strategies to Mitigate the Impacts of HPPV ....................................................... 16

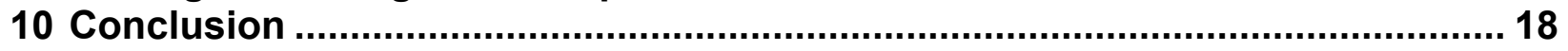

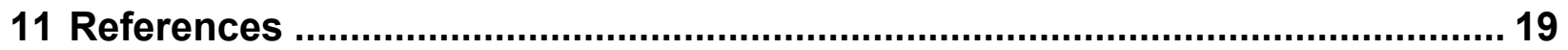

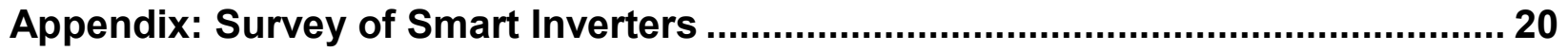

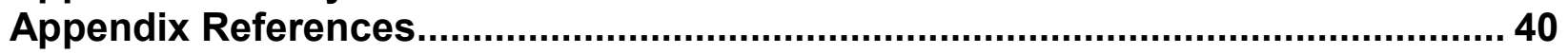




\section{List of Figures}

Figure 1. Structure of a PV power plant ........................................................................................... 1

Figure 2. Overview of interconnection screening process in the United States [4] ................................. 5

Figure 3. ANSI C84.1 (2011) (a) ranges and (b) voltage limits (120-V base)....................................... 12

\section{List of Tables}

Table 1. FERC Order 792 Fast-Track Criteria.................................................................................. 4

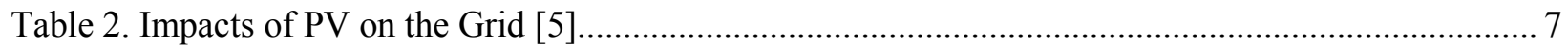

Table 3. Useful Penetration Ratios for Engineering Analysis [5] ..................................................... 8

Table 4. Synchronization Parameter Limits for Interconnection to an Electrical Power System [8] ......... 13

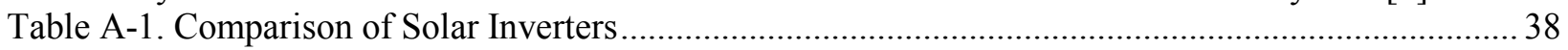




\section{Introduction}

There are two main types of electrical solar power systems: concentrating solar thermal and photovoltaic (PV). Currently, most of the installed solar power capacity is PV. As shown in Figure 1, a PV power plant usually consists of solar panels, inverters, a substation, and a point of interconnection to the transmission network.

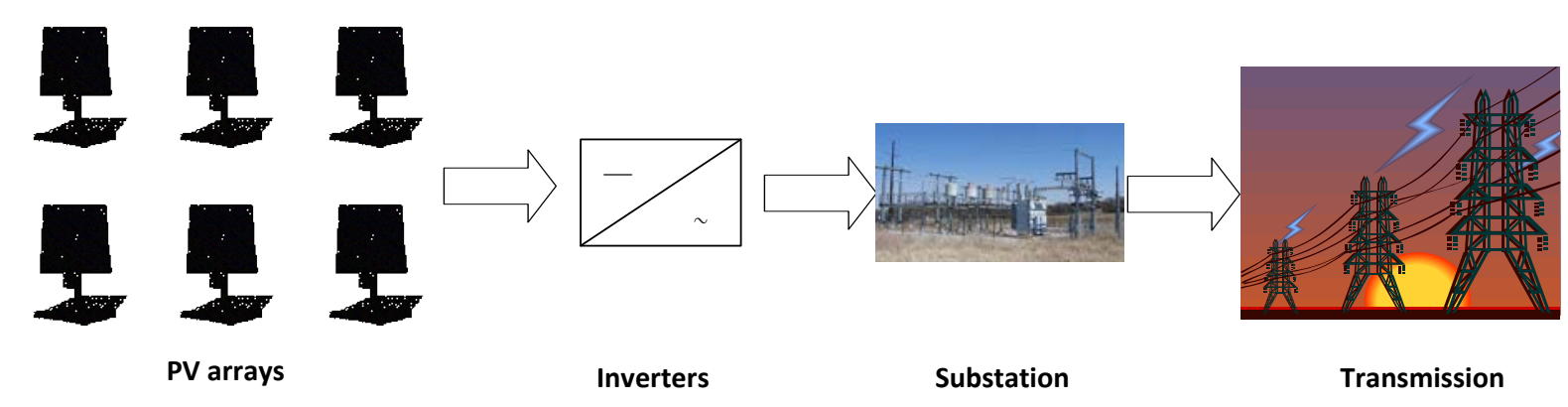

Figure 1. Structure of a PV power plant

High levels of PV generation within a system may lead to impacts on the grid system, including violations of voltage, thermal, and protection criteria [1]. To determine possible strategies to mitigate the impact of HPPV, it is crucial to understand the current criteria, requirements, and technology.

This report aims to provide an overview of select U.S. utility methodologies involved with system planning and system impact studies. It covers Federal Energy Regulatory Commission's (FERC's) orders related to PV power systems interconnection, as well as U.S. state interconnection standards and procedures. It references key technical requirements specified in the Institute of Electrical and Electronics Engineers (IEEE) Standard 1547 Standard for Interconnecting Distributed Resources with Electric Power Systems and certain safety requirements from UL 1741 Standard for Inverters, Converters, Controllers and Interconnection System Equipment for Use With Distributed Energy Resources. These regulations are analyzed in their specifications for power monitoring, grounding, synchronization, connection to the overall distribution system, back-feeds, disconnecting means, abnormal operating conditions, and power quality.

In addition, the report includes a survey of 10 major commercial solar PV inverters and their technical parameters and features. As the manufacturers upgrade their products, new models will become commercially available to reflect newly implemented technologies as well as the new grid codes in the targeted market regions. Similarly, recommendations and revisions to the standards may take place as the penetration level of renewables on the grid increases and new technologies develop in future years. This report is based on the current conditions of the grid and the available technologies at the time this report was prepared. 


\section{Federal Energy Regulatory Commission Orders}

In the United States, the Federal Energy Regulatory Commission (FERC) regulates approval to construct electricity generation, transmission, or distribution facilities. FERC continues to pursue market reforms to allow all resources, including variable renewable energy resources, to compete in jurisdictional markets on a level playing field [1].

In August 2003, FERC issued Order 2003, requiring utilities to adopt standard procedures and a standard agreement for the interconnection of large generator facilities. The commission requires public utilities to provide interconnection services to generating facilities that have a capacity more than $20 \mathrm{MW}$.

In June 2005, FERC issued Order 661, which amended its regulations to require public utilities to append their Large Generator Interconnection Agreement and standard procedures and technical requirements for the interconnection of large wind generation.

In December 2005, FERC issued Order 661-A, which specified low-voltage ride-through capability (LVRT), supervisory control and data acquisition (SCADA), and reactive power/power factor design standards.

Although these FERC orders were issued with wind power as the focus, it is recognized that similar interconnection requirements should be applicable to large solar power plants. In 2012, the North American Electric Reliability Corporation issued the Special Assessment:

Interconnection Requirements for Variable Generation, which aimed to enhance procedures and standards for the interconnection of variable generation, including large wind and solar power projects, through additions to or modifications of existing standards.

At the state and distribution levels, the American National Standards Institute (ANSI)/IEEE 1547 is the dominant standard governing the technical interconnection requirements of solar power systems; however, revisions and enhancements to IEEE 1547 are being developed (2015-2017) for high-penetration PV deployment in the context of the smart grid. 


\section{System Interconnection Process}

\subsection{Large Generator Interconnection Procedure}

Interconnection procedures were standardized in 2003 under FERC Order 2003, which established the Large Generator Interconnection Agreement requiring all generators under FERC jurisdiction with more than $20 \mathrm{MW}$ of generation capacity to abide by standard procedures for interconnection. For large generator interconnection projects, the interconnection customer first submits an interconnection request and a refundable deposit to the transmission provider. The request must include the proposed site data, date of commercial operation, and technical data on the generators and equipment.

Next, the transmission provider performs an interconnection feasibility study with shortcircuit/fault duty and steady-state (thermal and voltage) analyses. This process should be completed within 45 calendar days.

The transmission provider also performs an interconnection system impact study which includes short-circuit, stability, power flow, and other necessary analyses. This process is normally completed within 90 calendar days of application submission. These system impact studies help evaluate the total cost of the project, required time, and other factors that need to be considered.

\subsection{Small Generator Interconnection Procedure}

For small generator interconnection projects, which are less than $10 \mathrm{MW}$ or $20 \mathrm{MW},{ }^{1}$ FERC issued Order 2006, Order 2006-A, and Order 2006-B. FERC Order 2006 established the Small Generator Interconnection Procedure, which specified that a fast-track process applies to generating facilities that have a capacity less than $2 \mathrm{MW}$. For certified, inverter-based, small generating facilities that have a capacity less than $10 \mathrm{~kW}$, the $10-\mathrm{kW}$ inverter process is suitable for use. For generating facilities that have a capacity larger than $2 \mathrm{MW}$ but smaller than $20 \mathrm{MW}$, Section 3 of the study process of FERC order 792 should be used. In response to the rapid increase in distributed solar PV deployment, FERC issued Order 792 in November 2013 as an amendment to FERC Order 2006. The updated interconnection guidelines allow inverter-based interconnections up to $5 \mathrm{MW}$ to qualify for the fast-track process if the generating system's capacity is less than or equal to the minimum load on the distribution line of interconnection. The limit is significantly lower than $5 \mathrm{MW}$ for distributed energy resources (DER) systems on $15 \mathrm{kV}$ class and below. The new order 792 allows the fast-track process for interconnecting to the transmission provider's transmission system to also apply to the distribution system.

Eligibility to apply for the interconnection fast track is based on the generator type and size as well as the voltage and type of line at the point of interconnection. The fast-track criteria are summarized in Table 1.

\footnotetext{
${ }^{1}$ FERC Order 2006 defined a small generator as no more than $20 \mathrm{MW}$, although different local jurisdictions define small generators with varying capacities. Technical guidelines for the range between $10 \mathrm{MW}$ and $20 \mathrm{MW}$ are defined in IEEE P1547.5-Draft Technical Guidelines for Interconnection of Electric Power Sources Greater than 10 MVA; however, the draft technical guidelines did not become official technical guidelines.
} 
Table 1. FERC Order 792 Fast-Track Criteria

\begin{tabular}{lll}
\hline $\begin{array}{l}\text { Line Voltage I } \\
\text { Distribution Class }\end{array}$ & $\begin{array}{l}\text { Fast-Track Eligibility } \\
\text { Regardless of Location }\end{array}$ & $\begin{array}{l}\text { Fast-Track Eligibility on a } \\
\text { Mainline }^{\mathbf{a}} \text { and } \leq \mathbf{2 . 5}\end{array}$ \\
$\begin{array}{lll}\text { Electrical Circuit Miles } \\
\text { from Substation }\end{array}$
\end{tabular}

${ }^{a}$ For the purposes of this table, a mainline is the three-phase backbone of a circuit. It typically constitutes lines that have wire sizes of 4/0 American wire gauge, $336.4 \mathrm{kcmil}, 397.5 \mathrm{kcmil}, 477 \mathrm{kcmil}$, and $795 \mathrm{kcmil}$.

${ }^{\mathrm{b}}$ An interconnection customer can determine this information about its proposed interconnection location in advance by requesting a pre-application report.

In addition to changes to the requirements for fast-track interconnections for solar PV systems, FERC included electricity storage systems in the definition of small generator facilities in the Order 792 update; therefore, electricity storage systems using inverter-based interconnections also qualify for fast-track application. 


\section{State Interconnection Standards and Procedures}

Despite updates to FERC's Small Generator Interconnection Procedure and Small Generator Interconnection Agreement in 2013 to lower the barriers for distributed high-penetration PV (HPPV) systems, FERC Order 792 and Order 2006 serve only as guidelines for states to model their own interconnection rules for small generators. Procedures for interconnections on local distribution lines and qualifying facilities are specified by the distribution utility and regulated by the state public utilities commission.

Prior to 2000, utilities determined requirements for PV interconnection on a case-by-case basis, often based on FERC's Large Generator Interconnection Procedure. However, because distributed generators are connected to medium-voltage distribution lines, the Large Generator Interconnection Procedure for high-voltage transmission lines was more complex and expensive than necessary [1].

In 2000, California became one of the first states to implement comprehensive procedures for distribution system interconnections through the Electricity Tariff Rule 21 ("Rule 21"), which was adopted by the California Public Utilities Commission and the California Energy Commission. Rule 21 has been updated several times as the California solar market has grown. It serves as a basis for the development of technical standards, rules, and procedures in the United States [2].

Rule 21 stipulated a "screening process" for utilities to determine the level of study needed, aimed toward reducing the cost and increasing the speed of interconnecting distributed generation [3]. The engineering review process for interconnection requests includes initial review screens, supplemental review screens, and a detailed study screen. This process has been adopted by FERC's Small Generator Interconnection Procedure and various states and utilities in various forms. A simplified typical interconnection screening process is illustrated in Figure 2.

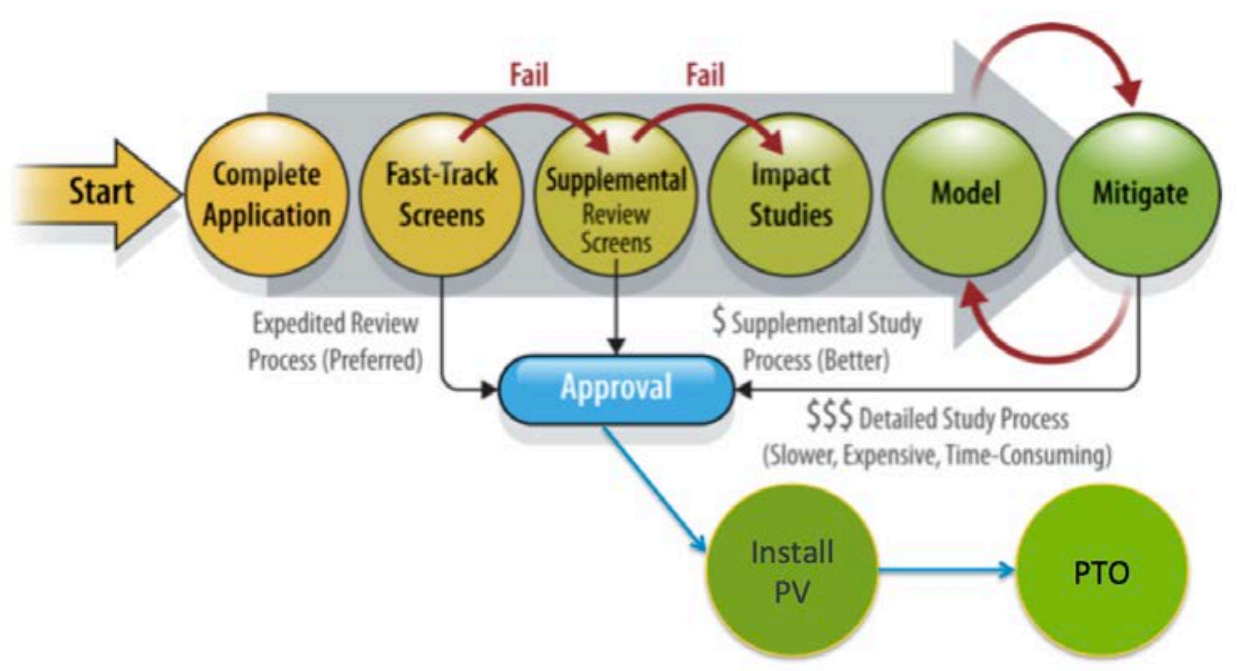

Figure 2. Overview of interconnection screening process in the United States [4] 
In an update to Rule 21 in December 2014, the California Public Utilities Commission added technical specifications for smart inverters to improve grid performance under HPPV. Key revisions to the technical requirements for inverters include the following seven aspects: antiislanding protection, voltage ride-through, frequency ride-through, dynamic volt-VAR operation, ramp rates, power factor, and soft-start reconnection [6].

Similar to FERC's Small Generator Interconnection Procedure for inverter-based distributed generators, the Massachusetts Department of Public Utilities No. $1219^{2}$ specifies that the distributed generation interconnection application must follow one of three review approaches: simplified, expedited, or standard. The criteria for each are based on the type and size of generators, amount of load, and the location on the grid. The simplified approach applies to radial grids that have total power delivered by PV less than $10 \mathrm{~kW}$ in single-phase systems or 25 $\mathrm{kW}$ in three-phase systems. The expedited approached applies to all other radial systems that have total power delivered by PV greater than $10 \mathrm{~kW}$ in single-phase systems or $25 \mathrm{~kW}$ in threephase systems. The standard approach applies to all other projects-i.e., those that do not meet the simplified or expedited review requirements.

\footnotetext{
${ }^{2}$ Massachusetts Department of Public Utilities No. 1219 was implemented in 2013. It replaced No. 1176, which was issued in 2009.
} 


\section{Impacts of HPPV Power Plants}

Historically, solar power plants are relatively small in capacity compared to large nuclear, natural gas, or coal-powered plants. However, with the rapid development of large, utility-scale solar power projects and distributed PV projects, high penetrations of variable generation sources have raised concerns due to their impacts on both the distribution systems and transmission networks. The variability and unpredictability of PV generation are often-cited concerns. Solar power plants on the grid may impact voltage deviations, protection coordination, transformer connections, fault currents, bidirectional power flow, synchronization, and harmonics. Table 2 summarizes some of the key impacts of PV on the grid.

Table 2. Impacts of PV on the Grid [5]

\begin{tabular}{|c|c|c|c|c|}
\hline$\%$ of Generation & $\leq 2 \%$ & $\leq 10 \%$ & $\leq 30 \%$ & $100 \%$ \\
\hline $\begin{array}{l}\text { Grid Penetration } \\
\text { Scenario }\end{array}$ & $\begin{array}{l}\text { Low level of PV with } \\
\text { relatively stiff grid } \\
\text { connection }\end{array}$ & $\begin{array}{l}\text { Moderate level of } \\
\text { PV with relatively } \\
\text { soft grid } \\
\text { connection }\end{array}$ & $\begin{array}{l}\text { High level of PV } \\
\text { with capacity of } \\
\text { grid less than the } \\
\text { load demand }\end{array}$ & $\begin{array}{l}\text { PV operates } \\
\text { part time as an } \\
\text { island or } \\
\text { microgrid }\end{array}$ \\
\hline $\begin{array}{l}\text { PV Impact and its } \\
\text { Role in the Grid }\end{array}$ & $\begin{array}{l}\text { Very low, not } \\
\text { significant to grid } \\
\text { operation }\end{array}$ & $\begin{array}{l}\text { Non critical, can } \\
\text { affect distribution } \\
\text { voltage near PV }\end{array}$ & $\begin{array}{l}\text { Critical to power } \\
\text { delivery and } \\
\text { meeting demand }\end{array}$ & $\begin{array}{l}\text { Primary power } \\
\text { source for } \\
\text { stand-alone } \\
\text { operation }\end{array}$ \\
\hline $\begin{array}{l}\text { Interconnection } \\
\text { and Integration } \\
\text { Objectives }\end{array}$ & $\begin{array}{l}\text { No interference, } \\
\text { good citizen, and } \\
\text { compatible }\end{array}$ & $\begin{array}{l}\text { Manage any local } \\
\text { distribution } \\
\text { impacts }\end{array}$ & $\begin{array}{l}\text { Engage PV for } \\
\text { system operations } \\
\text { and control }\end{array}$ & $\begin{array}{l}\text { Rely on PV for } \\
\text { stability and } \\
\text { regulation }\end{array}$ \\
\hline $\begin{array}{l}\text { Rules/Standard } \\
\text { Operating } \\
\text { Procedures }\end{array}$ & $\begin{array}{l}\text { IEEE 1547-2003 } \\
\text { current practice } \\
\text { radial feeders }\end{array}$ & $\begin{array}{l}\text { Modified } 1547 \text { add } \\
\text { network and } \\
\text { penetration limits }\end{array}$ & $\begin{array}{l}\text { New rules include } \\
\text { operation and grid } \\
\text { support } \\
\text { requirement }\end{array}$ & $\begin{array}{l}\text { Stand-alone } \\
\text { rules that are } \\
\text { system } \\
\text { dependent }\end{array}$ \\
\hline $\begin{array}{l}\text { Main Concerns } \\
\text { with Respect to } \\
\text { Dynamic Grid } \\
\text { Impacts }\end{array}$ & 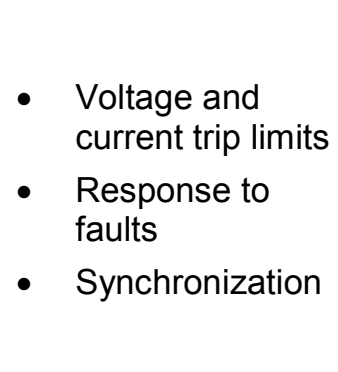 & $\begin{array}{ll}\text { - } & \text { Interference } \\
\text { - } & \text { } \text { Recovery } \\
\text { - } & \text { times } \\
\text { - Islanding } \\
\text { - } & \text { Coordination }\end{array}$ & $\begin{array}{ll}\text { - } & \text { Availability } \\
\text { - } & \text { Regulation } \\
\text { provided } \\
\text { - } & \text { Ramping } \\
& \text { response } \\
\text { - } & \text { Interactions of } \\
\text { machine } \\
\text { controls }\end{array}$ & $\begin{array}{ll}\text { - } & \text { Availability } \\
\text { - } & \text { Load } \\
& \text { following } \\
\text { - } & \text { Voltage } \\
\text { control } \\
\text { - } & \text { Normal and } \\
\text { reserve } \\
\text { capacity }\end{array}$ \\
\hline
\end{tabular}

When conducting an engineering analysis, the following ratios, shown in Table 3 , can be very useful in determining penetration level: (1) minimum load to generation; (2) stiffness factor; (3) fault factor; and (4) ground source impedance. 
Table 3. Useful Penetration Ratios for Engineering Analysis [5]

\begin{tabular}{|c|c|c|c|c|}
\hline \multirow{2}{*}{ Type of Ratio } & \multirow{2}{*}{ Application } & \multicolumn{3}{|c|}{ Suggested Penetration Level } \\
\hline & & Very Low & Moderate & Higher \\
\hline \multirow{4}{*}{$\begin{array}{l}\text { Minimum load to } \\
\text { generation }\end{array}$} & \multirow{4}{*}{$\begin{array}{l}\text { Ground fault overvoltage } \\
\text { Islanding analysis }\end{array}$} & $>10$ & 10 to 5 & Less than 5 \\
\hline & & $\begin{array}{l}\text { Synchronous } \\
\text { generation }\end{array}$ & $\begin{array}{l}\text { Synchronous } \\
\text { generation }\end{array}$ & $\begin{array}{l}\text { Synchronous } \\
\text { generation }\end{array}$ \\
\hline & & $>6$ & 6 to 3 & Less than 3 \\
\hline & & inverters & inverters & inverters \\
\hline \multirow{2}{*}{ Fault factor } & $\begin{array}{l}\text { Overcurrent device } \\
\text { coordination }\end{array}$ & \multirow{2}{*}{$>100$} & \multirow{2}{*}{100 to 20} & \multirow{2}{*}{ Less than 20} \\
\hline & $\begin{array}{l}\text { Overcurrent device } \\
\text { ratings }\end{array}$ & & & \\
\hline \multirow{4}{*}{ Stiffness factor } & \multirow{4}{*}{ Voltage regulation } & $>100$ & 100 to 50 & Less than 50 \\
\hline & & $\mathrm{PV} /$ wind & $\mathrm{PV} /$ wind & $\mathrm{PV} /$ wind \\
\hline & & $>50$ & 50 to 25 & Less than 25 \\
\hline & & steady source & steady source & steady source \\
\hline \multirow{2}{*}{$\begin{array}{l}\text { Ground source } \\
\text { impedance }\end{array}$} & $\begin{array}{l}\text { Ground fault } \\
\text { desensitization }\end{array}$ & \multirow{2}{*}{$>100$} & \multirow{2}{*}{100 to 20} & \multirow{2}{*}{ Less than 20} \\
\hline & $\begin{array}{l}\text { Overcurrent device } \\
\text { coordination and ratings }\end{array}$ & & & \\
\hline
\end{tabular}

With an increasing number of PV systems interconnected to the grid, engineers should also consider other factors that could influence the stability of the power grid, including seasonal, daily, or minute-level solar power fluctuation, PV inverters, a low capacity factor, inaccurate forecasting, energy storage, and bidirectional power flow.

The following sections will provide an overview of how current standards address these potential system impacts, as well as strategies for mitigation. 


\section{Technical Interconnection Requirements of HPPV}

Integrating large amounts of distributed generation onto the distribution network may affect the operation of the system. The level of PV penetration will proportionally affect the operation of the distribution system - i.e., the higher the penetration level, the higher the impact on the grid. The electric utility industry and the PV industry have been working together to address the impacts related to integrating PV with power systems, including implementing and continuously updating IEEE 1547, IEEE Standard for Interconnecting Distributed Resources with Electric Power Systems. First published in 2003, IEEE 1547 recommends technical requirements for distributed generation interconnections. The Energy Policy Act of 2005 established as the national standard for the interconnection of distributed generation in the United States. IEEE 1547 is suitable to all distributed resource technologies that have an aggregate capacity of 10 MW or less at the point of common coupling. ${ }^{3}$

The following rules should be required before connecting high-penetration PV to the grid, but they are applicable to any distributed generation source.

\subsection{Voltage Regulation}

The first rule concerns voltage regulation, which is the often cited as the main concern for utilities $^{4}$. The voltage at the customer end must be kept at a certain level that is required to operate customer equipment (e.g., lights, appliances, and other plug-in equipment) within ANSI voltage limits. Injecting leading reactive power into the system or drawing lagging reactive power may affect the voltage profiles. IEEE 1547 prevents distributed generation from actively regulating voltage at the point of common coupling to the electric utility. However, in September 2013 IEEE 1547a was added so that the new standard allows the distributed generation sources to regulate the voltage at the point of common coupling if the utility approves. Changes in distributed generation output caused by changes in weather may affect a utility's effort to regulate voltage. In addition, today's inverters can control the AC voltage with different means of controlling reactive power.

\subsection{Power Monitoring}

IEEE 1547 requires that any individual generation source rated $250 \mathrm{KVA}$ or higher at the point of interconnection must provide the following:

- Connection status

- Real power output

- Reactive power output

- Operating voltage.

\footnotetext{
${ }^{3}$ The standard is written considering the distributed resource is a $60-\mathrm{Hz}$ source.

${ }^{4}$ See NREL/EPRI report Current Utility Screening Practices, Technical Tools, Impact Studies, and Mitigation Strategies for Interconnecting PV on the Electric Distribution Systems at http://www.epri.com/abstracts/Pages/ProductAbstract.aspx?Productid=000000003002003277
} 
Power monitoring provides guidance to ensure personnel safety and addresses certain operating concerns. It may also be helpful for utilities that wish to understand the contribution of energy from larger distributed generation systems.

\subsection{Grounding}

IEEE 1547 requires that the grounding scheme of distributed generation must maintain voltage within equipment ratings during abnormal conditions such as short-circuit faults or islanding. In addition, the distributed generation grounding must not interfere with the coordination of ground-fault protection schemes proposed by the electric utility company. If the distributed generation is connected to multiple grounded neutral points, the following criteria must be followed:

- The distributed generation must be effectively grounded.

- The distributed generation must provide protective devices to detect ground-fault overvoltage on the grid and to disconnect from the grid.

\subsection{Synchronization}

Distributed generation in general may cause voltage fluctuations when connected to the distribution system or a weak grid. To connect distributed generation to a distribution system, IEEE 1547 requires some automatic or manual synchronization techniques to keep the frequency, voltage magnitude, and phase angle within a certain acceptable level; this is generally achieved with the use of inverters (power electronics).

\subsection{Connection to the Distribution System}

UL 1741 requires all protection elements to be rated before connecting a distributed generation source to the utility grid. In addition, IEEE 1547 requires that the distributed generation source must not cause any repeated opening and reclosing of the network protection elements.

\subsection{Back-Feeds}

IEEE 1547 requires that distributed generation sources do not back-feed into the grid during an outage, a situation often referred to as an "unintentional island". This can be accomplished using the following methods:

- An inverter uses internal methods to sense a loss of voltage or frequency, and disconnects the distributed generation system within $2 \mathrm{~s}$.

- Use various techniques to detect islanding and then disconnect the distributed generation source from the grid.

- Manually disconnect switches operated by the electric utility company to ensure that the distributed generation sources do not back-feed into the grid. 
- Direct transfer the trip signal from the electric utility company to the switches to disconnect the distributed generation source from the grid.

- In practice, many of the larger utilities in the United States have eliminated requirements for the utility external disconnect switch and apply direct transfer trips as the exception due to high cost [7].

\subsection{Disconnecting Means}

IEEE 1547 requires visible disconnecting means between the electric utility grid and the distributed generation sources when required by an electric utility company. The disconnecting means must:

- Provide isolation of the distributed generation source from the grid.

- Prevent unintended energization of the grid when workers are present.

- Ensure that the switches are operated without involving an operator's contact with live parts.

- Clearly label back-fed devices with a warning that all contacts may be energized.

\subsection{Abnormal Operating Conditions}

IEEE 1547 requires that voltage and frequency must be kept within an acceptable level during normal operation. During abnormal operation, the distributed generation sources must not provide power to the grid unless the distributed generation sources are required to stay connected under low voltage ride through period. These requirements are given below:

- Distributed generation sources do not energize the electric utility grid when the grid is faulted.

- Distributed generation sources disconnect from the grid before reclosure operation.

- Protective relays for the distributed generation sources must monitor the voltage and the frequency.

- Distributed generation sources must not be reconnected to the grid after the fault until the fluctuation of voltage and frequency lie within an acceptable level.

\subsection{Power Quality}

IEEE 1547 requires distributed generation sources to avoid:

- Flicker

- Harmonics

- DC current injection into the grid. 


\section{Key Technical Requirements}

The following sections summarize the key technical requirements for distributed generation interconnection per IEEE 1547 and FERC Order 661A-Appendix G. The requirements address many of the potential impacts of distributed generation PV, such as voltage regulation, grounding design, communications, reactive power capability, and protection requirements.

\subsection{IEEE 1547}

Voltage regulation describes the process and equipment necessary to maintain voltage within acceptable limits. The primary objective of the area electrical power system voltage regulation is to provide each customer connected to the area electrical power system with voltage that conforms to the design limitations of the customer's utilization equipment. [3] IEEE 1547 stipulates that distributed generation may not cause any customer's voltage to fall outside of the voltage Range A of ANSI C84.1 American National Standard for Electric Power Systems and Equipment-Voltage Ratings $(60 \mathrm{~Hz})$, as shown in Figure 3.

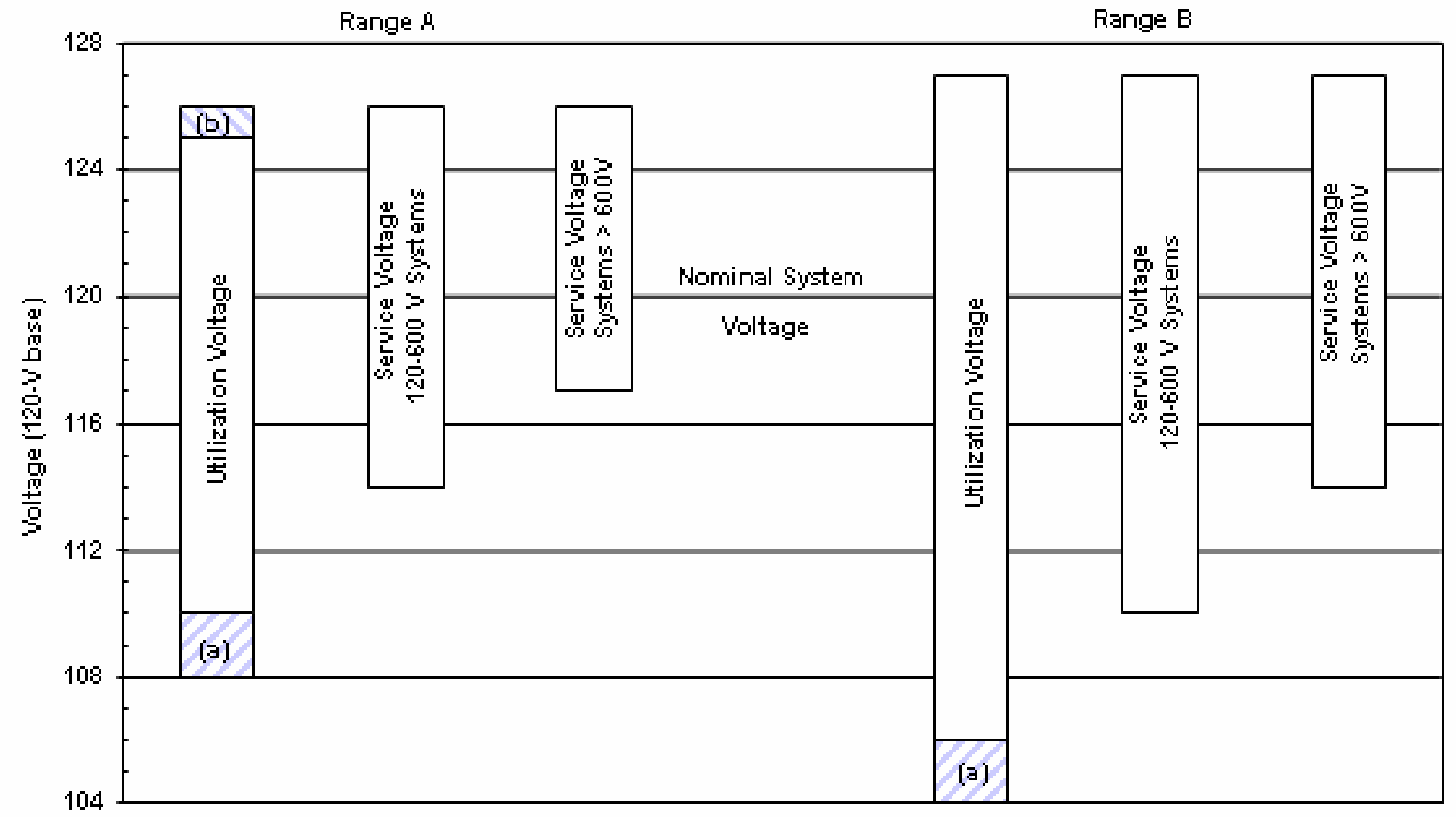

Figure 3. ANSI C84.1 (2011) (a) ranges and (b) voltage limits (120-V base) Notes:

1. The shaded portions of the range do not apply to circuits that supply lighting loads.

2. The shaded portions of the range do not apply to $120-\mathrm{V}$ to $600-\mathrm{V}$ systems.

3. The difference between the minimum service and minimum utilization voltages is intended to allow for a voltage drop in the customer's wiring system. This difference is greater for service at more than $600 \mathrm{~V}$ to allow for an additional voltage drop in transformers between service voltage and utilization equipment. Other countries have different standards. For example, the International Electrotechnical Commission (IEC) $61000-2-2$ (2002) mentions that the normal operational tolerances are $\pm 10 \%$ of the nominal voltage.

The grounding design of the distributed generation interconnection should not cause overvoltages that exceed the rating of the equipment connected to the area electrical power system or significantly modify the coordination of the ground fault protection. 
The distributed generation should be parallel with the area electrical power system without causing a voltage fluctuation at the point of common coupling more than $\pm 5 \%$ of the voltage level of the area electrical power system at the point of common coupling. The distributed generation should also meet the flicker requirements of IEEE 1547-2003 4.3.2.

IEEE 1547 requires the distributed generation to have synchronization parameter limits, as listed in Table 4.

\section{Table 4. Synchronization Parameter Limits for Interconnection to an Electrical Power System [8]}

\begin{tabular}{llll}
\hline $\begin{array}{l}\text { Aggregate Rating } \\
\text { of Distributed Generation } \\
\text { Units (KVA) }\end{array}$ & $\begin{array}{l}\text { Frequency Difference } \\
(\mathbf{\Delta f}, \mathrm{Hz})\end{array}$ & $\begin{array}{l}\text { Voltage Difference } \\
(\mathbf{\Delta V}, \%)\end{array}$ & $\begin{array}{l}\text { Phase Angle } \\
\text { Difference }(\boldsymbol{\Delta} \boldsymbol{\Phi})\end{array}$ \\
\hline $0-500$ & 0.3 & 10 & 20 \\
$>500-1,500$ & 0.2 & 5 & 20 \\
$>1,500-10,000$ & 0.1 & 3 & 10 \\
\hline
\end{tabular}

Additional requirements for distributed generation interconnection under IEEE 1547 include:

- The distributed generation output shall not trip any cycling of network protectors.

- The network equipment loading and fault interrupting capacity shall be within the addition of distributed generation.

- The distributed generation should not energize the area electrical power system when the area electrical power system is de-energized.

- A single distributed generation unit of $250 \mathrm{kVA}$ or more or aggregate distributed generation of $250 \mathrm{kVA}$ or more at a single point of common couple shall monitor its connection status, real power output, reactive power output, and voltage at the point of distributed generation connection.

- A readily accessible, lockable, visible-break isolation device shall be located between the area electrical power system and the distributed generation unit only if required by the utility and allowed by state interconnection rules. In many states, PV systems of 10kW and smaller are not required to have this AC External Disconnect Switch.

- The interconnection system shall have the ability to withstand electromagnetic interference (EMI) according to IEEE C37.90.2-2004 (B43). The influence of the electromagnetic interference shall not result in a change in state or a fault operation of the interconnection system.

- The interconnection system shall have the ability to withstand voltage and current surges according to the environments described in IEEE Std. C62.41.2-2002 (B48) or IEEE Std. C37.90.1-2002 (B42).

- The interconnection system paralleling device should have the ability to withstand $220 \%$ of the interconnection system rated voltage. 
- The DC current injected to the interconnection system should be less than $0.5 \%$ of the fully rated output current at the point of distributed generation connection.

- The distributed generation shall detect the unintentional islanding and stop energizing the area electrical power system within 2 seconds of formation of an island.

\subsection{FERC Order 661A-Appendix G of the Large Generator}

\section{Interconnection Agreement}

According to FERC Order 661-A, the power factor should be maintained within the range of 0.95 leading to 0.95 lagging, measured at the point of interconnection if the transmission provider's system impact study shows that such a requirement is necessary to guarantee safety or reliability.

Communication includes provision of analog and digital signals, including hardened voice communications, as requested by the transmission owner and/or the transmission provider for the remote terminal unit (RTU), frame relay, or public switched telephone systems.

For protection, the transmission operator will build a protective relay scheme to protect the transmission system from faults occurring in the interconnection facilities and transmission system. The interconnection customer should provide protection for the generating facility and all related equipment from faults occurring on its facilities and from faults occurring on the transmission operator's transmission system. 


\section{PV Power Plant Design, Engineering Studies, and System Interconnections}

The key components of a PV power system include collector systems, collector substations and interconnect substations, transmission lines, reactive power compensation systems, and energy storage systems. Some of the key factors in designing a PV power plant include:

- Typical physical design deliverables, including location, foundations, conduit, trench and duct banks, grounding, lightning protection, fence and signage, control building, conduit schedules, and bills of materials.

- Typical protection and control design deliverables, including measuring and relaying singleline diagrams, DC and AC schematic diagrams, panel designs and bill of materials, wiring diagrams, AC and DC systems diagrams and panel board designs, cable designs, equipment specifications, relay control logic diagrams, and configuration files.

- Engineering studies and analysis, including geotechnical studies, short-circuit studies, coordination studies, reactive power studies, conductor ampacity studies, conductor selection studies, cable and trench length studies, and collector system losses studies.

- Equipment, installation, and testing. The typical utility-scale installation may reduce as the price of PV panels reduces in the future years.

- SCADA in PV power substations. SCADA is used to send data from Point A to Point B or from and end device to a user interface. This process may have some intermediate steps. SCADA systems need to monitor the current status of the equipment, measure data, allow control of the plant output, generate output reports on production and operation, and export data to other applications (forecasting systems, historical trending). By using SCADA systems, engineers could remotely monitor a PV power system to increase efficiency, lower cost, manage assets, and analyze the status of the systems.

- Reactive power compensation and energy storage systems.

- Reactive power capabilities requirements are as follows:

_ - -0.95 leading to 0.95 lagging "standard" capability

_ -0.90 leading to 0.90 lagging "optional” capability.

$\circ$ The reactive compensation equipment used in a substation may include mechanically switched shunt capacitor and mechanically switched shunt reactor banks or inverterbased dynamic compensator mechanically switched shunt capacitors and mechanically switched shunt reactors.

- The technical requirements for some interconnections may require energy storage. Energy storage aids in frequency response (10\% minimum of rated $\mathrm{MW})$, ramp rate control (limits ramp rate to $10 \%$ of rated $\mathrm{MW} /$ minute), and curtailment mitigation (generation time shifting). 


\section{Strategies to Mitigate the Impacts of HPPV}

The impacts of HPPV on the system can be mitigated through several measures. The following outlines possible strategies for the key concerns during planning and design.

Possible strategies for system protection include:

- Using fuses between the generator and substation.

- Distribution system protective devices should be replaced with protective devices that have directional protection function.

- A trip of the source circuit can send a transfer trip from the source substation to the generator to solve one or more of several protection concerns. Transfer trip requires a reliable communications channel.

- The source substation protection designs can be modified to include tripping the feeder terminal breaker on circuits that have interconnected generation.

Possible strategies for improving steady-state performance include:

- Upgrade substation transformers to reduce overloads or voltage violations.

- Move the distributed generation closer to the substation source.

- Replace temperature- or time-controlled capacitor switching with local voltage control, current control, or reactive power control. Centralized capacitor dispatch may also be used with the installation of appropriate communications.

- Change voltage regulator settings or provide voltage regulators designed to operate properly with reverse power flow to operate correctly in the presence of distributed generation.

Possible strategies for improving power quality include:

- UL1741 and IEEE 1547 have strict requirements for harmonics. However, externally generated grid harmonics may occasionally or persistently interfere with the PV inverter operation. Additional line filter, different distributed generation interface technology, or vendor tuning of the interface controls can reduce the levels of harmonics or flicker problems.

- Active filters can be considered to reduce harmonics. Future inverters may be able to provide compensating current to mitigate harmonics.

- Relocating the distributed generation closer to the substation may help reduce flicker problems.

- For temporary or transient overvoltage problems, the surge arrester with appropriate voltage ratings might need to be included, subject to maintaining adequate protective margins for the insulation. A change in transformer connection type, supplemental grounding transformers, or distributed generation control tuning might help. 
- Flicker and voltage sags could be mitigated with dynamic-responding VAR capability built into the PV inverter controller; or in the large PV plant, it could be separate compensation equipment, especially if it is connected to a weak grid.

Possible strategies for improving system stability include:

- Implementing protective schemes so that the system can detect, isolate, or clear faults before the system becomes unstable. The critical clearing times can be determined from the stability study. At the machine level, strategies are very important. For example, a power system stabilizer may be added, distributed generation inertia may be changed, and a more aggressive exciter or governor may be used.

- Under voltage and overvoltage fault ride through capabilities of distributed generation can help improve system stability.

- Active load controls or demand response programs can help stability of system with HPPV. 


\section{Conclusion}

This report examines select U.S. utility methodologies in planning for grid systems with high levels of PV generation. It explores the federal, state, and utility-level regulations and rule, as well as specifications outlined in international standards. Through analysis of these regulations and standards' specifications for power monitoring, grounding, synchronization, connection to the overall distribution system, back-feeds, disconnecting means, abnormal operating conditions, and power quality, several recommended strategies are highlighted to mitigate the potential impacts of HPPV on the grid.

Policy makers, grid operators, and the solar industry can reference these suggested mitigation strategies to ensure system protection, improve steady-state performance, enhance power quality, and improve system stability. Different grid structures, local conditions, and penetration levels of renewables should be considered when determining appropriate mitigation strategies to accommodate PV.

Advanced inverters can be part of several mitigation strategies. The appendix contains a survey of 10 major commercial solar PV inverters and describes their technical features and capabilities for reference. 


\section{References}

1. Keyes, Jason B., and Kevin T. Fox. Comparison of the Four Leading Small Generator Interconnection Procedures. (Technical Report.) Cocoa, FL: Solar America Board for Codes and Standards, 2008; p. 1.

http://www.solarabcs.org/about/publications/reports/interconnection/index.html.

2. Fox, Kevin, Sky Stanfield, Laurel Varnado, Thad Culley, Michael Sheehan and Michael Coddington Updating Small Generator Interconnection Procedures for New Market Conditions. (Technical Report.) NREL/TP-5400-56790. Golden, CO: National Renewable Energy Laboratory, 2012. http://www.nrel.gov/docs/fy13osti/56790.pdf.

3. IEEE PES Tutorial on "Renewable Plant Design and System Interconnection," 2014 IEEE PES T\&D Conference \& Exposition, April 2014.

4. Coddington, M; B. Mather. "Mitigation Measures for Distributed Interconnection." Presentation for Distributed Generation Interconnection Collaborative, July 9, 2014. http://www.nrel.gov/tech deployment/pdfs/2014-0709 mitigation measures for distributed pv interconnection.pdf.

5. Coddington, M., B. Kroposki, T. Basso, K. Lynn, C. Herig, and W. Bower. "High-Penetration Photovoltaic Standards and Codes Workshop." NREL/TP-550-48378. Paper presented at the Solar Electric Power Association Conference, Denver, CO, May 2010. http://www.nrel.gov/docs/fy10osti/48378.pdf.

6. California Public Utilities Commission. Interim Decision Adoption Revisions to Electric Tariff Rule 21 for Pacific Gas and Electric Company, Southern California Edison Company, and San Diego Gas and Electric Company to Require "Smart" Inverters. California Public Utilities Commission Decision 14-12-035. December 18, 2014.

7. Coddington, M., R. Margolis, and J. Aabakken. Utility-Interconnected Photovoltaic Systems: Evaluating the Rationale for the Utility-Accessible External Disconnect Switch. NREL/TP-58142675. Golden, CO: National Renewable Energy Laboratory, 2008. http://www.nrel.gov/docs/fy08osti/42675.pdf.

8. IEEE. 1547-2003: IEEE Standard for Interconnecting Distributed Resources with Electric Power Systems. 2003. 


\section{Appendix: Survey of Smart Inverters}

This section includes a survey of 10 major solar PV inverters and their technical features, protections, and advantages as well as a comparison of their unique features and efficiencies. The information are obtained and summarized from the manufacturers' websites at the time this report was prepared. It is expected that new products and new capabilities may be added as the advanced technologies becomes available in the near future, or as the manufacturers target a new market regions with a stricter grid code requirements.

\section{Fronius}

\section{Products}

Fronius IG Plus

- 3.0-1 UNI

- 3.8-1 UNI [1].

\section{Features}

- On-site grounding selection

- CEC weighted efficiency: 95.5\%

- Well suited for outdoor or indoor installations

- DC disconnect integrated

- Safety with the new power plug

- AC output voltage is field programmable.

\section{Protection}

- Ground fault protection: Internal ground fault detector/interrupter

- DC reverse polarity protection

- Islanding protection (internal)

- Over temperature.

\section{Technical Advantages}

- Ground fault protection: The grounding system of the inverter is connected to the PV array, and if ground fault occurs in the DC wiring, the solar inverter is automatically disconnected from the grid.

- Galvanic isolation: The high-frequency transformer is responsible for galvanic isolation.

Fronius IG Plus Advanced

- $3.0-1$

- $3.8-1$

- $5.0-1$ 
- $6.0-1$

- 7.5-1 UNI [2].

\section{Features}

- Active and reactive power control, low voltage ride-through

- CEC weighted efficiency: $95.5 \%$

- High-frequency transformer

- Arc-fault protection

- $8 \mathrm{~W}$ of nighttime power consumption

- Designed for indoor and outdoor installations

- Integrated DC disconnect

- Field programmable AC output voltage

- Integrated WiFi interface

- 10-year warranty; optional 15-year available.

\section{Protection}

- Ground fault protection: Internal ground fault detector/interrupter

- DC reverse polarity protection

- Islanding protection (internal)

- Over-temperature

- Arc-fault circuit protection: Internal arc-fault circuit interrupter.

\section{Technical Advantages}

- Module manager: The module manager keeps all Fronius IG inverters at the maximum power point with fast and exact maximum power point tracking (MPPT).

- MIX concept in the design of Fronius's PV inverters: By employing and combining three power stages intelligently in different weather conditions, the inverter can work more efficiently, and the lifetime can be extended.

- The MIX concept is the concept of getting the maximum power harvest out of partial load ranges (e.g., on cloudy days) through a clever combination of multiple power stages in each inverter. The power stages in Fronius inverters divide up the work depending on operating hours and only operate as many power stages as required to efficiently process available power from the PV array.

Design: The Fronius IG Plus inverter includes a maximum power harvest; a built-in six-circuit string combiner; integrated, lockable DC disconnect; and significantly improved efficiency and reliability. 


\section{Products}

SB 2000HFUS, SB 2500HFUS, and SB 3000HFUS [3]

\section{Features}

- CEC weighted efficiency: 97\% (SB 2000HFUS) and 96.5\% (SB 2500HFUS/SB3000HFUS)

- OptiTrac MPPT for the best tracking efficiency

- OptiCool actively manages temperature

- Galvanic isolation

- Integrated DC switch disconnect

- Slim enclosure mounts in between wall studs

- Plug-in grounding with ground fault detector/interrupter

- Reduced weight

- Quick module for quick and easy configuration

- Modern graphic display

- Bluetooth technology.

\section{Protection}

- DC reverse-polarity protection

- AC short-circuit protection

- Galvanically isolated

- Overvoltage protection.

\section{Technical Advantages}

- Anti-islanding protection: Islanding occurs when distributed generation provides power even after the electric power supply has been cut off from the utility grid. Anti-islanding is avoided by feeding the distributed generation with reactive current (lagging and leading in a periodical manner).

- Ground fault detection: The inverter is switched off when the ground fault current exceeds the specified limit of 1 Ampere.

- Overvoltage protection: Varistors function by diverting the excess current (due to high voltage) from the devices/components and hence provide protection from overvoltage.

- Short-circuit and overload: AC and DC circuit breakers are inherent in the inverter to prevent short-circuit/overload.

- Grid synchronization: RS485 is inherent in the inverter as the type of communication between the solar inverter and grid. 
- SMA's OptiTrac technology searches for the optimum operating point and thus makes the inverter very efficient. 


\section{Outback Power}

\section{Products}

GS8048A, GS4048A, GS7048E, and GS3548E [4]

\section{Features}

- CEC weighted efficiency of $92.5 \%$ for GS8048A and GS4048A

- Advanced battery-charging capabilities

- Adjustable input voltage

- Grid-interactive and stand-alone capability

- Dual AC inputs

- Five-year warranty.

\section{Technical Advantages}

- Change in temperature: A remote temperature sensor is inherent in the inverter to maintain its temperature. When temperature decreases, it increases the charging voltage; when temperature increases, it decreases the voltage.

- Offset mode: When DC power produced by the PV array is more than the demand, excess power is fed into the grid. Also, if the DC power produced is less than the demand, then there is a reduction in usage of the AC source by the inverter. This faculty is available in the following modes (details below): support, grid zero, grid tied.

- Load shedding: It is necessary to maintain supply and demand to prevent a major power outage or blackout.

- Capacity increment: The inverter's capacity can be increased by connecting 10 units in parallel (also known as parallel stacking).

- Advance battery charge is a profile option to support leading-edge battery technologies, such as lithium-ion and others, and offers enhanced diagnostics for improved performance.

\section{Different Modes of Operation}

- Generator mode: This mode allows disrupted waveforms, and it is suitable for various kinds of $\mathrm{AC}$ sources.

- Support mode: This mode is beneficial during large load requirements.

- Grid-tied mode: This mode is utilized when the power produced is more than the demand, then extra power can be fed to the grid.

- UPS and backup mode: This mode acts as a support system during grid malfunction. The backup mode utilizes less power compared to the UPS mode.

- GridZero: This mode is designed to optimize the use of renewable energy, battery storage, and utility power. It powers the loads for a majority of a time period that would otherwise overwhelm the utility grid. 
- Mini grid mode: In this mode, the inverter has the capability to act as a grid. It operates through the utility grid when the electric power stored in its batteries is too low for load(s) operation. 


\section{Satcon}

Products

Equinox LC

- EQX-LC-12-UL

- EQX-LC-16-UL

- EQX-LC-20-UL

- EQX-LC-24-UL [5].

\section{Features}

- Easy to install

- Ideal for roof/indoor/outdoor installation

- Operating range: $-13^{\circ} \mathrm{F}$ to $+131^{\circ} \mathrm{F}\left(-25^{\circ} \mathrm{C}\right.$ to $\left.+55^{\circ} \mathrm{C}\right)$

- Integrated monitoring

- VAR control (range specified $=-0.95$ to +0.95 )

- String combiner boxes not required

- Maximum efficiency: $98.2 \%$

- Five-year warranty

- UL 1741, IEEE 1547 certified.

PowerGate Plus

- $30 \mathrm{~kW}, 50 \mathrm{kw}, 75 \mathrm{~kW}, 100 \mathrm{~kW}, 135 \mathrm{~kW}, 250 \mathrm{~kW}, 375 \mathrm{~kW}$, and $500 \mathrm{~kW} \mathrm{[6].}$

\section{Features}

- Easy grid connectivity

- CEC efficiency: 96\% (PVS-75)

- Faster communication

- Operating range: $-4^{\circ} \mathrm{F}$ to $+122^{\circ} \mathrm{F}\left(-20^{\circ} \mathrm{C}\right.$ to $\left.50^{\circ} \mathrm{C}\right)$

- String level currents monitoring

- Maximize system uptime and power production

- Conforms to UL 1741 and IEEE 1547 standards.

\section{Protection}

- Real and reactive power control

- Low-voltage ride through

- Power factor control

- Ground fault detection and interruption 
- Galvanic isolation.

Equinox

- $500 \mathrm{~kW} \mathrm{UL}$

- $625 \mathrm{~kW} \mathrm{UL}[6]$

Features

- Easier to install onto the grid

- CEC efficiency of 95.5\% for 500-kW model (SDMS0500UL320Xx)

- Fast communications

- Easily consolidated into SCADA systems

- Operating range: $-4^{\circ} \mathrm{F}$ to $+122^{\circ} \mathrm{F}\left(-20^{\circ} \mathrm{C}\right.$ to $\left.+50^{\circ} \mathrm{C}\right)$ :

- Ideal for desert, tropical, and winter climates

- Solar shields available for dissipating solar radiation — reduces heat buildup

- Conforms to UL 1741 and IEEE 1547 standards.

\section{Protection}

- Real and reactive power control

- Power factor control

- Low-voltage ride-through

- Galvanic isolation. 


\section{Schneider}

\section{Products}

Conext RL-Single-Phase Grid-Tied Inverter

- RL $3000 \mathrm{E}$

- $\quad$ RL $4000 \mathrm{E}$

- RL $5000 \mathrm{E}$

Conext CL-Three-Phase Grid-Tied Inverter

- CL $20000 \mathrm{E}$

- CL 25000 E [8], [9].

\section{Features}

- Dual MPPT feature - both shaded and non-shaded part of PV (single phase)

- Efficient in case of partial shading (single phase)

- Peak efficiency: 97.5\% efficiency (single phase), 98.4\% (three phase)

- $\quad 95.5 \%$ CEC weighted efficiency for Conext TX 3800 NA (3.8-kW grid-tied inverter)

- Integrated DC switch, RS 485 communication (single and three phase)

- Local and remote monitoring of PV performance

- Operating temperature: $-4^{\circ} \mathrm{F}$ to $+149^{\circ} \mathrm{F}$ (single phase), $-13^{\circ} \mathrm{F}$ to $+140^{\circ} \mathrm{F}$ (three phase).

\section{Protection}

- Active power control: It is controlled in two ways:

- Power (discontinuation of MPPT)

- Frequency.

- Reactive power control: It is controlled in four ways:

- It is based on specified power factor and active power by the user.

- The constant value of the reactive power is fed irrespective of the instantaneous condition.

$\circ$ The reactive power is controlled based on the AC voltage.

- The inverter determines the power factor and active power, and it accordingly controls the reactive power.

- Low-voltage ride-through: The inverter sets off if the grid voltage goes below the defined value for more than the specified time period.

- Surge protection: It is available in the three-phase grid-tied inverter. 
GE

Products

General Electric-5-kW Solar Inverter [12]

\section{Features}

- Two-stage power conversion

- Low-voltage ride-through, zero-voltage ride-through, and high-voltage ride-through

- I/O data: String current, temperature, and irradiance monitoring

- $95.5 \%$ CEC weighted efficiency

- Local and remote monitoring using SCADA.

Protection

- Active and reactive power control

- Voltage control

- Frequency control

- Ramp rate control. 


\section{Advanced Energy}

\section{Products}

Single-Phase String Inverters

- AE 1TL 1.8-4.2 (IEC)

- AE 3TL 8-23 (IEC)

- AE 3TL 12-23 (UL)

- AE 3TL 20/24 (JP)

- AE 3TL 40/46 (IEC)

- AE 3TL 333 (IEC).

Three-Phase String Inverters

- AE 3T1 8-23 (IEC)

- AE 3TL 12-23 (UL)

- AE 3TL 20/24 (JP)

- AE 3TL 333 (IEC).

Central Inverters-NX Transformerless

- AE $1000 \mathrm{NX}$

- $\mathrm{AE} 500 \mathrm{NX}$

- AE 500NX-HE

- $\mathrm{AE} 500 \mathrm{NX}-1 \mathrm{kV}$

- $\mathrm{AE} 333 \mathrm{NX}$

- AE250 NX.

TX Transformer-Based

- AE 500TX

- $\mathrm{AE} 260 \mathrm{TX}$

- $\mathrm{AE} 250 \mathrm{TX}$

- $\mathrm{AE}$ 100TX [13].

\section{Features}

- CEC weighted efficiency: 98\% (AE 1000NX, AE 500NX-HE), 97.5\% (AE 500NX, AE 3TL series), 96.5\% (AE 250TX), 97\% (AE 260TX)

- Operating temperature range: $-13^{\circ} \mathrm{F}$ to $+131^{\circ} \mathrm{F}$

- Passive cooling (string inverters) and forced-convection cooling (central inverters)

- Compliant with UL1741 and IEEE 1547 standards

- Data monitoring 
- SCADA support

- RS 485 communication.

\section{Protection}

- Power factor, frequency, and voltage control

- Active and reactive power control

- Ramp rate control

- Scheduling control

- Role-based access control.

For higher capacities $(500 \mathrm{~kW})$, it is economical to use central inverters, whereas string inverters should be preferred for capacities that range from $100 \mathrm{~kW}$ to $350 \mathrm{~kW}$ [14]. 


\section{ABB}

\section{Products}

Single-Phase String Inverters

- PVI-3.0/3.6/3.8/4.2

- PVI-5000

- PVI-6000

- UNO-2.0-I

- UNO-2.5-I

- UNO-7.6/8.6.

\section{Features of PVI-5000/6000-TL-OUTD [15]:}

- Suitable for residential and small commercial applications

- Single-phase and split-phase output grid connection

- Flexible

- Inherent real-time tracking

- Suitable for any climatic conditions

- $\quad$ Power factor $>0.995$

- Total harmonic distortion at rated power $<2 \%$

- $\quad$ CEC weighted efficiency $=96.5 \%$

- Operating temperature range: $-13^{\circ} \mathrm{F}$ to $+140^{\circ} \mathrm{F}\left(-25^{\circ} \mathrm{C}\right.$ to $\left.+60^{\circ} \mathrm{C}\right)$.

\section{Protection}

- Reverse polarity protection

- PV array ground fault detection

- Anti-islanding (meets UL 1741 and IEEE 1547 requirements)

- Overvoltage protection.

\section{Technical Advantages}

- Arc fault detection: With the help of current sensors and channels, the system detects any arc fault and detaches the inverter from the utility grid.

- Power derating occurs when temperature or voltage exceeds the specified limit.

Three-Phase String Inverters

- PVI-10.0-I

- PVI-12.0-I

- TRIO-20.0-TL

- $\quad$ TRIO-27.6-TL. 


\section{Features of TRIO-20.0/27.6-TL-OUTD [16]}

- Peak efficiency ratings of $98.2 \%$

- No electrolytic capacitors

- Inherent AC and DC level protection, arc-fault circuit interruption

- Modbus is present for monitoring and controlling

- 10-year warranty, extended warranty for 15 and 20 years

- Operating MPPT voltage range: $200 \mathrm{~V}$ to $950 \mathrm{~V}$

- Maximum efficiency $97.5 \%$

- Operating temperature range: $-22^{\circ} \mathrm{F}$ to $+140^{\circ} \mathrm{F}\left(-30^{\circ} \mathrm{C}\right.$ to $\left.+60^{\circ} \mathrm{C}\right)$.

\section{Protection}

- Reverse polarity protection

- Overvoltage protection

- PV array ground fault detection

- Anti-islanding protection

- Meets UL 1741 and IEEE 1547 standards

- $\mathrm{DC}$ and $\mathrm{AC}$ surge protection

- Arc-fault circuit interruption. 


\section{Eaton}

\section{Products}

Power Xpert Solar 250-kW Inverter [17]

\section{Features}

- Three-phase grid-tied inverter

- CEC efficiency: 96\%

- PID control, surge protection (DC and AC)

- Reactive power and temperature controlled

- Better performance in different climatic conditions

- Fault tolerance (DC circuit breakers available)

- Inverter cannot be hacked easily

- UL 1741 and IEEE 1547 certified.

\section{Protection}

- Anti-islanding

- Overcurrent: AC circuit breaker present

- Reactive power control

Power Xpert Solar

- $1,500 \mathrm{~kW}$

- $1,670 \mathrm{~kW}[18]$.

\section{Features}

- Easy to install

- CEC efficiency: $98.5 \%$ (1,500-kW inverter), 96\% (1,670-kW inverter)

- Reliable: Works efficiently even during faults

- Inherent circuit breakers and surge protection

- UL 1741 certified

- Low-voltage ride-through, high-voltage ride-through, zero-voltage ride-through

- Temperature range: $-4^{\circ} \mathrm{F}$ to $+122^{\circ} \mathrm{F}\left(-20^{\circ} \mathrm{C}\right.$ to $\left.+50^{\circ} \mathrm{C}\right)$.

\section{Protection}

- Voltage and frequency control: Done through protection relay

- Ground fault, AC, and DC surge protection via SCADA

- Ramp control

- Anti-islanding. 


\section{Technical Advantages [19]}

- Fault tolerance: In case failure occurs, the inverter consists of three power stacks that can work independently, and hence the inverter remains functional even during a crisis.

- Power factor control: The ideal values of apparent, active, and reactive power (for a 1,500$\mathrm{kW}$ solar inverter) are 1.65 MVA, 1.5 MW, and $\pm 0.687 \mathrm{MVAr}$. Any changes in the specified limits lead to power derating. 


\section{SolarMax}

\section{Products}

MT A Series-String Inverters [20, 21]

\section{Features}

- CEC weighted efficiency: 97.5\% (SM 12MT2A), 97\% (SM 15MT3A, SM 18MT3A)

- Operating temperature range: $-13^{\circ} \mathrm{F}$ to $+140^{\circ} \mathrm{F}$

- RS 485 communication

- UL 1741, IEEE 1547 certified

- 10-year warranty

- Efficient monitoring.

\section{Protection}

- Inherent fault current diagnosis

- $\mathrm{DC}$ and $\mathrm{AC}$ surge protection, ground fault diagnosis

- Anti-islanding

- Overvoltage, overcurrent protection.

\section{Technical Advantages}

- Ground fault diagnosis: The inverter is detached from the utility grid when the specified limit of leakage current is surpassed.

- Overvoltage protection: Varistors are inherent in the inverter to prevent damage from overvoltage.

- $\mathrm{DC}$ and $\mathrm{AC}$ overcurrent protection: Circuit breakers are present to limit $\mathrm{AC}$ current. For DC current, the inverter constantly monitors its value and maintains it at the specified limit.

RX A series-Central Inverters [22]

\section{Features}

- Easy to install

- Operating temperature: $-13^{\circ} \mathrm{F}$ to $+122^{\circ} \mathrm{F}$

- Galvanic isolation absent

- RS 485 communication

- Quad MPPT

- UL 1741 and IEEE 1547 certified.

\section{Protection}

- Reactive power control

- Grid monitoring 
- Inherent arc fault protection. 
Table A-1. Comparison of Solar Inverters

\begin{tabular}{|c|c|c|}
\hline Manufacturer & Unique Qualities & CEC Weighted Efficiency [23] \\
\hline \multicolumn{3}{|l|}{ Fronius } \\
\hline $\begin{array}{l}\text { IG Plus } \\
(3.0-1 \mathrm{UNI} / \\
3.8-1 \mathrm{UNI})\end{array}$ & $\begin{array}{l}\text { AC output is field programmable and } \\
\text { suitable for different weather conditions }\end{array}$ & $95.5 \%$ \\
\hline \multicolumn{3}{|l|}{$\begin{array}{l}\text { IG Plus Advanced } \\
(3.0-1 / 3.8-1 / 5 \cdot 0-1 / \\
6.0-1 / 7.5-1 \text { UNI) }\end{array}$} \\
\hline SMA & $\begin{array}{l}\text { Good MPPT technology and highly } \\
\text { reliable in case of system faults }\end{array}$ & $\begin{array}{l}97 \% \text { (SB 2000HFUS), } 96.5 \% \text { (SB } \\
2500 \text { HFUS/SB3000HFUS) }\end{array}$ \\
\hline $\begin{array}{l}\text { Outback power } \\
\text { (GS8048A, } \\
\text { GS4048A) }\end{array}$ & $\begin{array}{l}\text { Can be operated in } 6 \text { different modes } \\
\text { depending on the user's requirement. } \\
\text { This is a unique quality compared to } \\
\text { other solar inverters available in the } \\
\text { market. }\end{array}$ & $92.5 \%$ \\
\hline Satcon & $\begin{array}{l}\text { Very high efficiency and no requirement } \\
\text { of string combiner boxes (used in many } \\
\text { inverters) }\end{array}$ & $\begin{array}{l}\text { 95.5\% for 500-kW model } \\
\text { (SDMS0500UL320Xx), } \\
\text { 96\% for } 75-\mathrm{kW} \text { model (PVS-75) }\end{array}$ \\
\hline \multirow[t]{2}{*}{ Schneider } & $\begin{array}{l}\text { Efficient in partial shading and good } \\
\text { power quality control }\end{array}$ & $\begin{array}{l}\text { Peak efficiency: } 97.5 \% \text { (single phase), } \\
98.4 \% \text { (three phase) }\end{array}$ \\
\hline & & $\begin{array}{l}\text { 95.5\% CEC weighted efficiency for } \\
\text { Conext TX } 3800 \text { NA (3.8-kW grid-tied } \\
\text { inverter) }\end{array}$ \\
\hline $\begin{array}{l}\text { General Electric } \\
(5 \mathrm{~kW})\end{array}$ & $\begin{array}{l}\text { Integrated with SunIQ; an advanced } \\
\text { monitoring system }\end{array}$ & $95.5 \%$ \\
\hline Advanced Energy & $\begin{array}{l}\text { High-efficiency, SCADA, and cooling } \\
\text { options available }\end{array}$ & $\begin{array}{l}\text { 98\% (AE 1000NX, AE 500NX-HE), } \\
\text { 97.5\% (AE 500NX, AE 3TL series), } \\
\text { 96.5\% (AE 250TX), 97\% (AE 260TX) }\end{array}$ \\
\hline $\begin{array}{l}\text { ABB } \\
\text { (PVI-5000/ } \\
6000-T L-O U T D)\end{array}$ & $\begin{array}{l}\text { Real-time tracking and wide operating } \\
\text { temperature range and hence suitable } \\
\text { for variant climates }\end{array}$ & $\begin{array}{l}96.5 \% \text { (single phase), } 97.5 \% \text { (three } \\
\text { phase) }\end{array}$ \\
\hline Eaton & $\begin{array}{l}\text { PID control, anti-hacking system } \\
\text { available } 97.5 \% \text { (SM 12MT2A), } 97 \% \\
\text { (SM 15MT3A, SM 18MT3A) }\end{array}$ & $\begin{array}{l}98.5 \%(1,500-\mathrm{kW} \text { inverter }), 96 \%(1,670- \\
\mathrm{kW} \text { inverter) }\end{array}$ \\
\hline SolarMax & Quad MPPT, high efficiency & $\begin{array}{l}\text { 97.5\% (SM 12MT2A), 97\% (SM 15MT3A, } \\
\text { SM 18MT3A), 95\% (SM 75TS-A) }\end{array}$ \\
\hline
\end{tabular}

Note that the following three terms are used in the survey comparison:

- MPPT: This is defined as the process of continually determining the operating point at which the PV generator achieves its maximum output performance.

- Conversion efficiency: This indicates the percentage of the power that is produced from the solar modules that can be fed into the public grid. However, the best possible weather conditions for operating a solar power system are assumed when calculating the value.

- CEC (California Energy Commission) weighted efficiency: This is calculated from several efficiencies at different operating points that are weighted based on the frequency with which 
they occur at a specific location in California. It is a measurement that better reflects the everyday partial load behavior. 


\section{Appendix References}

1. "Fronius IG Plus-3.0-1/3.8-1/5.0-1/6.0-1/7.5-1/10.0-1/11.4-1/11.4-3/12.0-3-Operating Instructions," Fronius, accessed September 2, 2014, http://www.fronius.com/cps/rde/xbcr/SID604C185A-

7BA1518F/fronius usa/BA Fronius IG Plus USA 4204260071 EA 012010200312 sna pshot.pdf.

2. "Fronius IG Plus Advanced-3.0-1/3.8-1/5.0-1/6.0-1/7.5-1/10.0-1/10.0-3/11.4-1/11.4-3/

12.0-3-Operating Instructions," Fronius, accessed September 2, 2014,

http://www.fronius.com/cps/rde/xbcr/SID-604C185A-

7BA1518F/fronius usa/42 04260158 EA 294276 snapshot.pdf.

3. "PV Inverter-SUNNY BOY 2000HF-US/2500HF-US/3000HF-U.S. Installation Guide," SMA America, accessed September 2, 2014, http://files.sma.de/dl/9524/SB20-30HF-US-IA-en12.pdf.

4. “Radian Series Inverter/Charger-GS8048A, GS4048A—Operator's Manual,” Outback Power Technologies, accessed September 2, 2014,

http://www.outbackpower.com/downloads/documents/radian_8048a_4048a/gs_8048a 4048a op erator.pdf.

5. "PV Inverters-Equinox Light Commercial (LC) UL-EQX-LC-12-UL/EQX-LC-16UL/EQX-LC-20-UL/EQX-LC-24-UL-Solution Sheet," Satcon Technology Corporation, accessed September 2, 2014, http://www.satcon.com/uploads/products/en/Equinox-LC-USUL.pdf.

6. "PV Inverters—PowerGate Plus 30-kW UL (PVS-30-UL) —Solution Sheet," Satcon Technology Corporation, accessed September 2, 2014, http://www.satcon.com/uploads/products/en/30kW-PG-US-UL.pdf.

7. "PV Inverters-Equinox 500-kW UL (EQX-500-UL)—Solution Sheet," Satcon Technology Corporation, accessed September 2, 2014, http://www.satcon.com/uploads/products/en/500kWEquinox-US-UL.pdf.

8. "Conext RL Photovoltaic Grid Tie Inverters—Conext RL 3000 E-S/3000 E/4000 E-S/4000 E/5000 E-S/5000 E-Installation and Operation Manual," Schneider Electric, accessed September 2, 2014, http://solar.schneider-electric.com/wpcontent/uploads/2014/06/IM201304 Conext-RL-Installation-and-Operation-Manual ENG9750687-01-01_Rev-B2.pdf.

9. "Conext CL Three-Phase Grid-Tied Inverters," Schneider Electric, accessed August, 2015, http://solar.schneider-electric.com/product/conext-cl/.

10. “Connext RL Single Phase Inverters," Schneider Electric, accessed September 2, 2014, http://solar.schneider-electric.com/product/conext-rl/, accessed August 2015. 
11. Prasad, Srikanta, and Ranjeet Kuberkar. "Application Note-Monitoring Options for Conext RL”, Schneider Electric, accessed September 2, 2014, http://solar.schneider-electric.com/wpcontent/uploads/2014/04/Conext-RL-Monitoring-Options-Application-Note.pdf.

12. "600-kW Solar Inverter-Operability, Performance, and Availability," General Electric Company, accessed September 2, 2014, http://site.ge-

energy.com/prod_serv/products/solar/en/downloads/GEA17910_SolarInverterBrochure.pdf.

13. "Solar Inverter Portfolio," Advanced Energy Industries, accessed September 2, 2014, http://solarenergy.advanced-energy.com/upload/File/AE_Data_Sheets/ENG-ProductPoster-20009.pdf.

14. "Advantages of Distributed and Central Architectures in Solar Arrays," Advanced Energy Industries, accessed September 2, 2014, http://solarenergy.advancedenergy.com/upload/File/White_Papers/ENG-String_Central_Architectures-270-01web.pdf.

15. "Solar Inverters_-Product Manual PVI-5000-6000-TL-S-US (-A) (5 to $6 \mathrm{~kW})$, , ABB, accessed September 2, 2014,

http://www05.abb.com/global/scot/scot232.nsf/veritydisplay/2b92da0c88b703ba85257cda007f3 b26/\$file/PVI-5000-6000-TL-S-US\%20(-A)\%20Product\%20manual.pdf.

16. "Solar Inverters-Product Manual TRIO-20.0/27.6-TL-US (20.0 to 27.6 kW)," ABB, accessed August, 2015, http://new.abb.com/power-converters-inverters/solar/string/threephase/trio-20-0kw-27-6kw.

17. "Harvest the Power of the Sun: Power Xpert Solar Utility-Scale Photovoltaic Inverters$1,500 \mathrm{~kW}$ and 1,670 kW," Eaton, accessed September 2, 2014,

http://www.eaton.com/Eaton/ProductsServices/Electrical/ProductsandServices/ElectricalDistribu tion/Grid-TieInverters/SolarInverters/1500kW/index.htm\#tabs-2.

18. "Aiming for Gridparity on Utility-Scale Solar Applications," (White Paper), Eaton, accessed September 2, 2014,

http://www.eaton.com/Eaton/ProductsServices/Electrical/ProductsandServices/ElectricalDistribu tion/Grid-TieInverters/SolarInverters/1500kW/index.htm\#tabs-2.

19. "Eaton Catalog — Volume 15, Tab 02-Commercial and Utility, Eaton, accessed September 2, 2014, http://www.eaton.com/Eaton/ProductsServices/Electrical/ProductsandServices/ElectricalDistribu tion/Grid-TieInverters/SolarInverters/1500kW/index.htm\#tabs-2.

20. "SolarMax MT A Series-12MT2 A/15MT3 A/18MT3 A-Installation and Maintenance Manual," accessed August, 2015, http://www.kolff.cl/descargas/Inversores/SolarMax_MT_A_Series_Installation_Manual.pdf.

21. "SolarMax MT Series_-Product Brochure," accessed August, 2015, http://www.solarmax.com/us/en/products/string-inverters/solarmax-mt-aseries $/ ?$ tab $=$ specifications. 
22. "SolarMax RX Series_-Product Brochure," accessed August, 2015, http://www.solarmax.com/en/products/central-inverters/solarmax-rx-serie/?tab=specifications

23. "List of Eligible Inverters per SB1 Guidelines," accessed September 2, 2014, http://www.gosolarcalifornia.ca.gov/equipment/inverters.php. 